\title{
Surface energy balance and melt thresholds over 11 years at Taylor Glacier, Antarctica
}

\author{
Matthew J. Hoffman, ${ }^{1}$ Andrew G. Fountain, ${ }^{2}$ and Glen E. Liston ${ }^{3}$ \\ Received 7 April 2008; revised 14 August 2008; accepted 3 October 2008; published 17 December 2008.
}

[1] In the McMurdo Dry Valleys, Victoria Land, Antarctica, melting of glacial ice is the primary source of water to streams, lakes, and associated ecosystems. To understand geochemical fluxes and ecological responses to past and future climates requires a physically based energy balance model. We applied a one-dimensional model to one site on Taylor Glacier using 11 years of daily meteorological data and seasonal ablation measurements. Inclusion of transmission of solar radiation into the ice was necessary to accurately model summer ablation and ice temperatures. Results showed good correspondence between calculated and measured ablation and ice temperatures over the 11 years. Ablation $\left(\sim 18 \mathrm{~cm} \mathrm{a}^{-1}\right)$ was dominated by sublimation with very few occurrences of melt (42 days during 11 years). Results also indicated that above freezing air temperatures did not necessarily result in melt and, in turn, melt occurred during subfreezing air temperatures under some conditions. For air temperatures near freezing, low wind speed was critically important for melt initiation. According to the model, subsurface melt, away from rocks and sediment in the ice, occurred three times more frequently than surface melt; occurs no deeper than $50 \mathrm{~cm}$ below the glacier surface; and was small, never exceeding $8 \%$ by mass. The magnitude of subsurface melting and the energy balance indicate that Taylor Glacier ice is intermediate in optical properties between snow and blue ice.

Citation: Hoffman, M. J., A. G. Fountain, and G. E. Liston (2008), Surface energy balance and melt thresholds over 11 years at Taylor Glacier, Antarctica, J. Geophys. Res., 113, F04014, doi:10.1029/2008JF001029.

\section{Introduction}

[2] The McMurdo Dry Valleys (MDV) are the largest icefree area, $4800 \mathrm{~km}^{2}$, in Antarctica [Drewry et al., 1982]. The valley floors are a patchwork of glacier ice, perennially icecovered lakes, and large expanses of bedrock and sandy, gravelly soils. Ephemeral streams convey water from the glaciers to the lakes for up to 10 weeks each summer [McKnight et al., 1999]. The source of meltwater is the lower elevations of the glaciers, the exposed ice in the ablation zones, because the snow covered accumulation zones rarely melt and when they do, the water refreezes in the colder snow layers at depth [Fountain et al., 1999]. Precipitation is small ( $<10 \mathrm{~cm}$ water equivalent) in the valley bottoms [Keys, 1980] and snow is not of direct hydrologic significance, because it generally sublimates before melting [Chinn, 1981; Gooseff et al., 2006]. Consequently, glacial melt is the critically important water source to the streams and lakes in the valleys. Aquatic ecosystems of algae, cyanobacteria, mosses, and

\footnotetext{
${ }^{1}$ Department of Geology, Portland State University, Portland, Oregon, USA.

${ }^{2}$ Department of Geology and Department of Geography, Portland State University, Portland, Oregon, USA.

${ }^{3}$ Cooperative Institute for Research in the Atmosphere, Colorado State University, Fort Collins, Colorado, USA.
}

Copyright 2008 by the American Geophysical Union. 0148-0227/08/2008JF001029\$09.00 diatoms are found in the streams [McKnight et al., 1999], and phytoplankton and benthic algal mats in the lakes [Priscu et al., 1999]. Runoff not only supplies water to these ecosystems but also conveys important nutrients [Foreman et al., 2004]. Therefore, the MDV landscape and ecosystems are sensitive to climate because small changes lead to large variations in liquid water availability [Dana and Wharton, 1998; Fountain et al., 1998]. To understand past environmental conditions, their legacies on current hydrochemical processes, and to anticipate future changes resulting from changing climate requires an understanding of glacial meltwater production.

[3] Past runoff modeling for the MDV has included both statistical and physically based approaches. Statistical models have examined the relation between temperature, solar radiation, and runoff [e.g., Bomblies, 1998; Dana et al., 2002; Jaros, 2003]. Ebnet et al. [2005] modeled seasonal runoff for all lake basins in Taylor Valley and did very well in parts of Taylor Valley and less well in windy regions such as Taylor Glacier. Process-based energy balance models have been employed to investigate spatial variations in the energy balance over the ablation zones of the MDV glaciers [Johnston et al., 2005; Lewis et al., 1999]. Ablation and melt varied greatly because of local topographic effects that cause increased air temperature, decreased wind speed, and, at times, increased radiation in sheltered depressions (e.g., channels, basins, cliff faces and bases [Johnston et al., 2005; Lewis et al., 1999; Chinn, 1987]). In summer, winds 


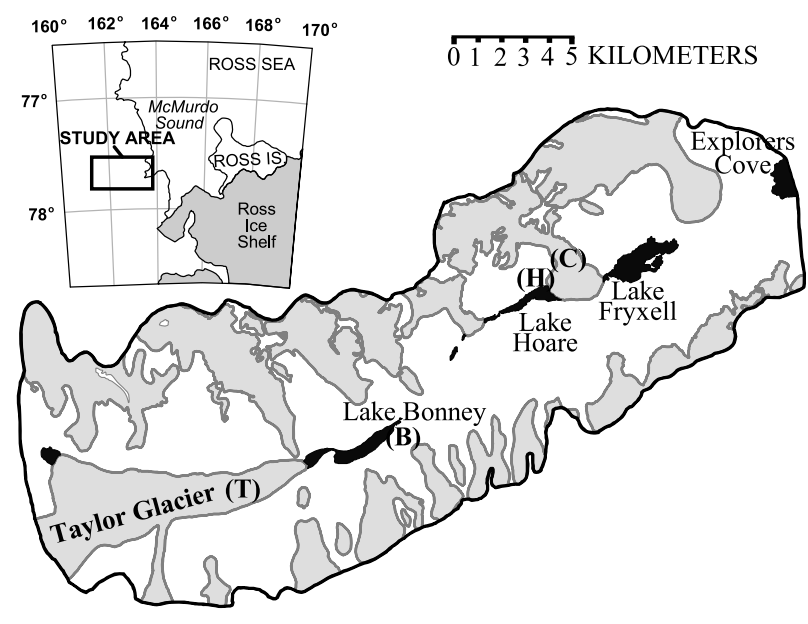

Figure 1. Location of Taylor Glacier (T), Lake Bonney (B), Lake Hoare (H), and Canada Glacier (C) meteorological stations within Taylor Valley. Glaciers in gray, lakes in black, and soil in white.

remove heat from the glacier surface through sensible and latent processes, because the summer air temperature is commonly colder than the ice surface. Heat losses are reduced in depressions in the ice surface where local winds are low and local air temperature high, leaving more energy available for melt, particularly at times of day when local radiation is increased on sloping surfaces. In some cases a feedback occurs. For example, on Taylor Glacier channels incised $\sim 20 \mathrm{~m}$ in the glacier surface experienced air temperature increased by $1.7^{\circ} \mathrm{C}$, wind speeds reduced by $\sim 50 \%$, and net shortwave radiation increased by up to $37 \%$ compared to adjacent local surfaces. Ablation (and melt) in the channel increased about 5 times greater than on adjacent horizontal surfaces which allowed the channels to deepen more rapidly than the adjacent surfaces [Johnston et al., 2005]. Similarly, winds are reduced along the $\sim 20 \mathrm{~m}$ high cliffs that form the lower glacier margins, and cliff melt can account for $15-20 \%$ of the total glacier runoff, despite comprising only $2 \%$ of the surface area of the ablation zone of nearby Canada Glacier [Lewis et al., 1999]. The energy balance also varies spatially because of changes in albedo caused by patches of sediment on the glacier surface. Experiments on Canada Glacier suggest that a thin sediment cover can potentially double summer melt [Lewis, 2001].

[4] These physically based studies have been useful for understanding the spatial variation of energy balance, but their limited duration (a few summer weeks) has precluded understanding of the day-to-day variation over the seasonal cycle, including the onset and termination of the melt season. Moreover, these studies do not adequately address the subsurface heating of the ice which can lead to subsurface melting and water flow [Fountain et al., 2004; Liston et al., 1999]. With over a decade of meteorological and mass balance observations in Taylor Valley [Doran et al., 2002; Fountain et al., 2006] we apply an energy balance model for the eventual prediction of streamflow in Taylor Valley. Here we test our capability to model 11 years of ablation at a daily time step and compare our results to blue ice areas elsewhere in Antarctica [e.g., Bintanja and Van Den Broeke, 1995b; Liston et al., 1999].

\section{Field Site: Taylor Glacier}

[5] We chose a glacier in Taylor Valley because it is a site of the Long-Term Ecological Research Project with 15 stream gauges to compare our future modeling results against. Taylor Glacier is an outlet of the east Antarctic Ice Sheet that terminates into Lake Bonney ( $57 \mathrm{~m}$ above sea level) at the west end of Taylor Valley, about $90 \mathrm{~km}$ from its source at Taylor Dome and $25 \mathrm{~km}$ from the coast of McMurdo Sound (Figure 1). The equilibrium line is approximately $70 \mathrm{~km}$ up glacier of the terminus, and only the lower $15 \mathrm{~km}$ occupy Taylor Valley (Figure 1). The surface ice in the ablation zone is generally white, bubbly ice (Figure 2). Our model test site was the meteorological station on the lower part $(4 \mathrm{~km}$ up glacier from the terminus) of Taylor Glacier $\left(77^{\circ} 42^{\prime} \mathrm{S}\right.$, $162^{\circ} 8^{\prime} \mathrm{E}$ ), chosen because the surface topography is smooth and relatively level, the surface is free of sediment, and snow accumulation is rare.

[6] The meteorological station was deployed in 1994 on Taylor Glacier at an elevation of $334 \mathrm{~m}$ asl as one of the twelve permanent meteorological stations maintained by the McMurdo Dry Valleys Long-Term Ecological Research project [Doran et al., 1995]. Continuous measurements are collected of air temperature, relative humidity, wind

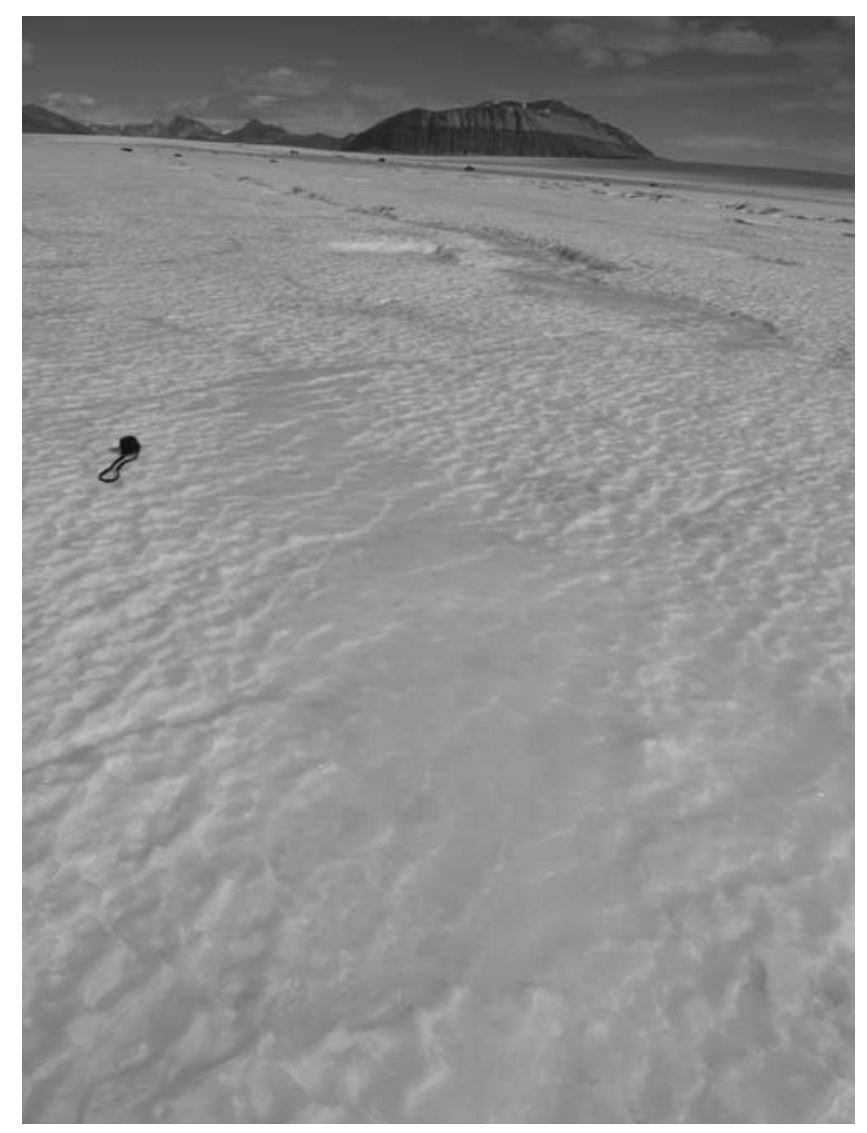

Figure 2. Surface of Taylor Glacier showing typical roughness and a melt/freeze patch of smooth ice. Camera case with strap is approximately $50 \mathrm{~cm}$ long. 


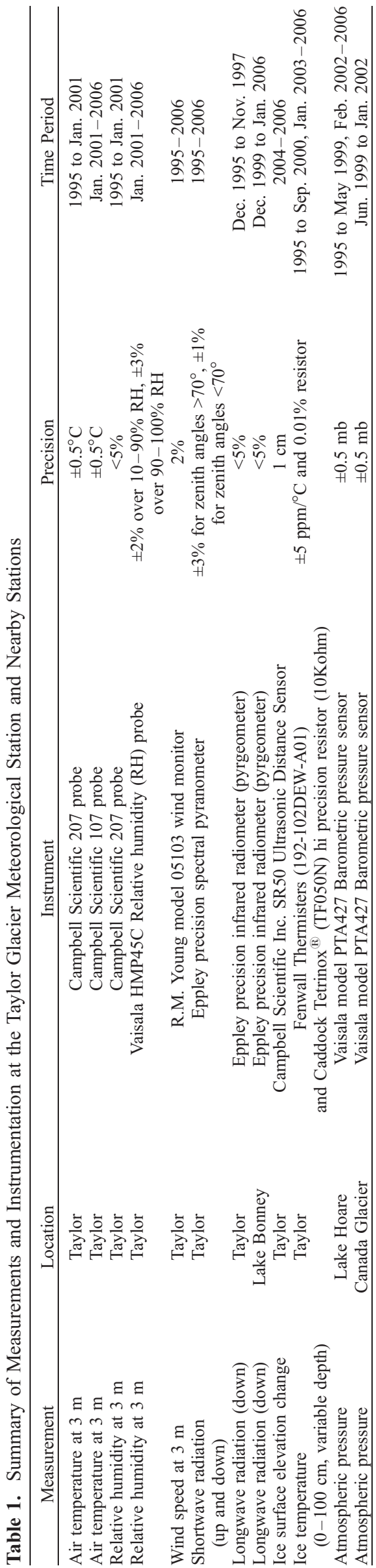

speed (all at $3 \mathrm{~m}$ ), incoming and outgoing shortwave (solar) radiation, incoming longwave (thermal) radiation, ice temperature, and distance to the ice surface for ablation and snowfall (Table 1). Most of the sensors collect data every $30 \mathrm{~s}$ (every $4 \mathrm{~s}$ for wind speed) and $15 \mathrm{~min}$ averages are stored on a solid state data logger. Ablation of the glacier surface causes the instrument height to increase over time and the station is periodically reset.

[7] Over the 11 year period, 1995-2006, the mean annual air temperature at Taylor Glacier was $-17.1^{\circ} \mathrm{C}$, with an average summer (December-January) temperature of $-3.0^{\circ} \mathrm{C}$. On average, 4.7 days per year had daily air temperatures warmer than $0^{\circ} \mathrm{C}$. Mean annual relative humidity was $60 \%$, with a slight increase in summer $(62 \%)$ lasting into April. Solar radiation is absent MayAugust, averages $290 \mathrm{~W} \mathrm{~m}^{-2}$ during December-January, and reaches a daily maximum of $\sim 400 \mathrm{~W} \mathrm{~m}^{-2}$. Wind speed averaged $5.1 \mathrm{~m} \mathrm{~s}^{-1}$ annually and was lower in summer (4.4 $\left.\mathrm{m} \mathrm{s}^{-1}\right)$. Katabatic winds, gravity-driven winds that typically reach high speeds and exhibit low humidity, are a characteristic feature of the MDV, reaching recorded speeds up to $37 \mathrm{~m} \mathrm{~s}^{-1}$ [Nylen et al., 2004]. The strongest and most frequent katabatic winds in MDV occur at Taylor Glacier, with a winter frequency greater than $50 \%$ and $15 \%$ during summer [Nylen et al., 2004]. During winter katabatic winds effectively increase average temperature by $3.5^{\circ} \mathrm{C}$, increase average wind speed by $3.2 \mathrm{~m} \mathrm{~s}^{-1}$, and decrease relative humidity by $8.5 \%$ at Taylor Glacier, with smaller effects during summer [Nylen et al., 2004]. These winds strongly affect ice ablation by generating large latent heat fluxes (sublimation) and redistributing snow [Van Den Broeke and Bintanja, 1995].

[8] Ablation on Taylor Glacier is manually measured against poles drilled into the ice, like elsewhere in the Taylor Valley [Fountain et al., 2006]. Stake heights are measured twice per year providing summer (mid-November to late January) and winter (late January to mid-November) seasonal totals of ablation with an accuracy of $\pm 0.7 \mathrm{~cm}$ water equivalent (weq) at the $95 \%$ confidence level. From this point onward we use the terms summer and winter to refer to the periods defined by the stake measurements, except where we explicitly define the seasons differently to allow direct comparisons to other studies. Snow depth and density were recorded for the single incidence of snow present during stake measurements that occurred during the study period. A stake located $20 \mathrm{~m}$ away from the meteorological station was used to compare against the modeled ablation values. In 2004 an ultrasonic distance sensor was installed to provide daily measurements of surface height.

\section{Modeling Approach}

\subsection{Description}

[9] Using a daily time step, we apply the one-dimensional model of Liston et al. [1999] because it accounts for both the surface energy balance and subsurface solar heating. The surface energy balance takes the form,

$$
\chi(1-\alpha) Q_{s i}+Q_{l i}+Q_{l e}+Q_{h}+Q_{e}+Q_{c}=Q_{m},
$$

where $\chi$ allocates the total solar radiation between the surface energy balance and the solar-radiation source term 
in the heat transfer equation (a modification from the original model), $\alpha$ is albedo, $Q_{s i}$ is incoming shortwave solar radiation, $Q_{l i}$ is incoming longwave radiation, $Q_{l e}$ is emitted thermal radiation, $Q_{h}$ is sensible heat flux, $Q_{e}$ is latent heat flux, $Q_{c}$ is heat conduction in the ice, and $Q_{m}$ is the energy available for melt, calculated as a residual. All heat flux terms have units of $\mathrm{W} \mathrm{m}^{-2}$, and a positive sign is energy directed toward the surface. $Q_{s i}, \alpha$, and $Q_{l i}$ are measured directly, and the terms that cannot be directly measured $\left(Q_{l e}, Q_{h}, Q_{e}, Q_{c}\right)$ are cast in a form that leaves surface temperature, $T_{0}$, as the only unknown [Liston et al., 1999]. The turbulent terms $Q_{h}$ and $Q_{e}$, are estimated using a bulk energy method with a correction for stability on the basis of the Monin-Obukhov theory [Brutsaert, 1982]. The only adjustable variable in the turbulent fluxes is the momentum surface roughness length, $z_{0}$. We set the scalar roughness lengths of temperature and water vapor equal to $z_{0}$, a simplification often made over smooth glacier surfaces in dry and cold climates [e.g., Bintanja and Van Den Broeke, 1995b; Lewis et al., 1999; Bintanja and Reijmer, 2001; Mölg and Hardy, 2004] that can potentially produce an overestimation of turbulent fluxes when applied to rougher surfaces. We ignored the effect of drifting snow on surface roughness [Schmidt, 1982] because snowfall is infrequent. $T_{0}$ is solved iteratively using (1), and if its value is above $0^{\circ} \mathrm{C}, T_{0}$ is reset to $0^{\circ} \mathrm{C}$, and the temperature difference is used to calculate melt energy and the corresponding volume of meltwater produced.

[10] $Q_{c}$ is calculated by a one-dimensional heat transfer equation,

$$
\rho_{i} C_{p} \frac{\partial T_{i}}{\partial t}=\frac{\partial}{\partial z}\left[k \frac{\partial T_{i}}{\partial z}\right]-\frac{\partial q}{\partial z}
$$

where $T_{i}(\mathrm{~K})$ is the ice temperature, $z(\mathrm{~m})$ is the vertical coordinate, $t(\mathrm{~s})$ is time, $C_{p}\left(\mathrm{~J} \mathrm{~kg}^{-1} \mathrm{~K}^{-1}\right)$ is the specific heat of the ice, and $q\left(\mathrm{~W} \mathrm{~m}^{-2}\right)$ is the solar radiative flux. In a change from the described Liston et al. [1999] model, the thermal conductivity of the ice, $k\left(\mathrm{~W} \mathrm{~m}^{-1} \mathrm{~K}^{-1}\right)$, is given by Paterson [1994], accounting for water fraction, if present:

$$
\begin{gathered}
k=\frac{2 k_{p} \rho}{3 \rho_{p}-\rho}, \\
k_{p}=9.828 \exp \left(-5.7 \times 10^{-3} T_{i}\right),
\end{gathered}
$$

where $\rho$ is ice density, and $k_{p}$ and $\rho_{p}$ are the thermal conductivity and density $\left(917 \mathrm{~kg} \mathrm{~m}^{-3}\right)$ of pure ice. The spectrally dependent solar-radiation source term $\partial q / \partial z$ is described in detail by Liston et al. [1999]. The surface energy balance (1) represents the upper boundary condition for (2), and the bottom boundary condition is no heat flux at depth $15 \mathrm{~m}$, approximately the depth of attenuation of the seasonal temperature variations and where the ice temperature equals the mean annual temperature [Paterson, 1994].

[11] Because snow accumulation on Taylor Glacier is rare and of short duration, we used a simple parameterization for snow events. When measured albedo is greater than 0.85 , we applied a snow layer to the glacier surface within the model. The snow layer was removed when measured albedo dropped below 0.7 or average daily wind speed exceeded $8.5 \mathrm{~m} \mathrm{~s}^{-1}$. These thresholds were determined from empirical observations using the ultrasonic distance sensor to detect snow accumulation on the glacier surface. When albedo measurements were unavailable (April-August), snow was ignored. We justify this because only three snow accumulation events occurred during the three winters that ultrasonic distance sensor data were available, all lasting less than a week. Because single-storm snow accumulation is typically less than $2 \mathrm{~cm}(\mathrm{H}$. Basagic, personal communication, 2008) and katabatic wind events occur with greater than 50\% frequency during winter [Nylen et al., 2004], snow is quickly removed during winter. We did not calculate ablation when snow is present in the model. We also did not change the thermal or optical characteristics of the ice when snow is present, because our observations indicate snow cover is thin ( $\sim$ centimeters $)$ and transient.

\subsection{Implementation and Calibration}

[12] Although $Q_{l i}$, is measured, about one-fifth of the record is missing (1 July to 18 December 1995, 18 November 1997 to 14 January 1998, 9 July to 11 November 1998 , 28 October to 16 November 2000, 4 July to 4 September 2003, 22 June to 28 December 2004, and 5 January to 30 June 2006). To complete the record we found that using the StefanBoltzmann equation with the parameterization for atmospheric emissivity, $\varepsilon$, used by Liston and Elder [2006] fit the data the best:

$$
\varepsilon=\kappa\left(1+Z_{S} \sigma_{c}^{2}\right)\left[1-X_{S} \exp \left(-Y_{s} e / T\right)\right]
$$

where $\sigma_{c}$ is the cloud fraction determined as a function of relative humidity, $e(\mathrm{~Pa})$ is atmospheric pressure, $T$ is air temperature $(\mathrm{K})$, and the coefficients $\kappa, X_{s}, Y_{s}$, and $Z_{s}$ are calculated as a function of elevation. We filled an 8 month gap in wind speed (winter 2003) using data from nearby stations adjusted with a polynomial regression between Taylor Glacier and those stations. Two other gaps in the meteorological record, of 8 days (January 2001) and 18 days (November 2002) in duration, were filled with the average value of the record before and after the gap equal to the length of the gap for each meteorological variable. For example, for the missing data spanning eight days, each day in the gap was filled using the average of the 8 days before the gap and the 8 days after. As mentioned, the height of the instruments is nominally $3 \mathrm{~m}$, but changes because of ice ablation. A linear interpolation between ablation stake measurements was used to estimate the change in instrument height with an uncertainty of less than $10 \mathrm{~cm}$. Atmospheric pressure was not measured at Taylor Glacier and we used the nearest measurements, at Canada Glacier and Lake Hoare about $23 \mathrm{~km}$ down valley, corrected for altitude at Taylor Glacier.

[13] The spectrally dependent solar-radiation source term described in detail by Liston et al. [1999] $\partial q / \partial z$ is a function of the solar spectrum (we retained that used by Liston et al. [1999]), the surface albedo (we used the measured snowfree average of 0.56), ice density (we used the value measured on ice cores from Canada and Commonwealth Glaciers of $\rho_{\text {ice }}=870 \mathrm{~kg} \mathrm{~m}^{-3}$ ), and ice grain radius. The calculations of the downward bulk extinction coefficient do not include the effects of bubbles or impurities, so we chose 


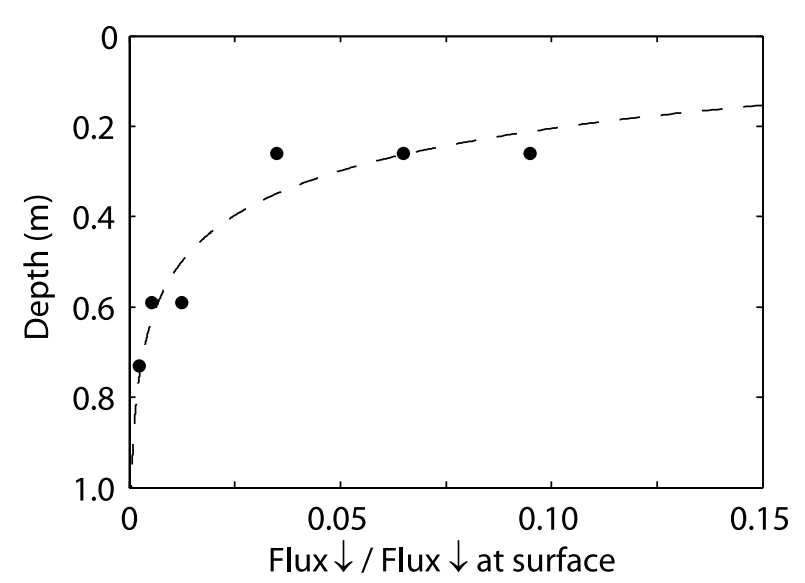

Figure 3. Measured (points) and modeled (line) subsurface solar radiation penetration for ice properties used in the model.

to estimate an "effective" ice grain radius by measuring the downward flux of solar radiation within the ice, rather than using a measured grain radius. We drilled three $27 \mathrm{~cm}$ diameter holes horizontally into a $\sim 1 \mathrm{~m}$ vertical cliff on the surface of Canada Glacier at depths of 26, 59, $73 \mathrm{~cm}$ below the upper surface and oriented to the sun so that the hole entrances were shaded by the cliff. Canada Glacier was used for logistical reasons; comparison of thin sections from both glaciers shows that both glaciers have ice with similar bubble content and grain radius (Canada: $r_{\mathrm{avg}}=2.7 \mathrm{~mm}$, Taylor: $r_{\text {avg }}=2.8 \mathrm{~mm}$ ). An Eppley broadband pyranometer was placed approximately level $1 \mathrm{~m}$ deep inside each of the holes facing upward to measure the downward solar radiation flux within the ice, while an additional pyranometer measured the downward flux at the surface. A black cloth fitted around the subsurface pyranometer absorbed light reflecting against the cylindrical walls of the hole and blocked any light from the hole entrance. The drilling of the hole and the placement of the pyranometer created disturbances to the ice and affected the upward flux below the pyranometer and, in turn, the backscattering that contributes to the downward flux above the pyranometer. We have neglected this effect for lack of a robust way to account for it. The best agreement with measurements of downward flux occurs with a model grain radius of $0.24 \mathrm{~mm}$ (Figure 3), an order of magnitude smaller than the measured grain radius. Bubbles present have a radius of 0.05 to $0.5 \mathrm{~mm}$. This suggests that scattering due to bubbles may dominate the scattering due to grain boundaries. However, additional measurements and modeling are necessary to conclusively determine such effects.

[14] The parameter, $\chi$, which partitions the net solar radiation between the surface and subsurface is based on the method of Bintanja and Van Den Broeke [1995b]. In so doing we essentially define the thickness of the air-ice interface or "surface" that interacts with the atmosphere over the duration of the time step, in our case, daily. The surface thickness, $d_{\chi}$, therefore gains energy from solar radiation through absorption at the surface equal to $\chi(1-\alpha) Q_{s i}$. Subsurface heating begins below depth $d_{\chi}$ and totals $(1-\chi)(1-\alpha) Q_{\text {si }}$, thereby conserving absorbed solar energy. To calibrate the model, $\chi$ and $z_{0}$ (roughness) were adjusted together through an iterative process to minimize the root mean square error (RMSE) in ablation for the 22 seasons (11 years) of measurements. We chose to calibrate our model with $z_{0}$ because profile measurements on MDV glaciers do not exist to determine $z_{0}$ directly. We recognize that model error will be included in our calibration parameter values, and they do not represent their true values. Because adjustment of $z_{0}$ affects the calculation of both summer and winter ablation, and adjustment of $\chi$ primarily affects summer, the calibration leads to a unique pair of values. The surface thickness, $d_{\chi}$, is a consequence of the adjusted $\chi$. On the basis of our field observations, we assume all surface melt is lost to runoff and subsurface melt is retained. The final calibration values were $\chi=0.817$, $d_{\chi}=13 \mathrm{~cm}$, and $z_{0}=0.25 \mathrm{~mm}$, which produce RMSE of $1.97 \mathrm{~cm}$ weq.

[15] To test our interpretation that $\chi$ is dependent on the chosen time step, we ran the model with an hourly time step for a single year (2005-2006) calibrated to monthly measurements of surface lowering (maintaining $z_{0}=0.25 \mathrm{~mm}$ ), with resulting values of $\chi=0.567$ and $d_{\chi}=4 \mathrm{~cm}$, consistent with our expectation. The root mean square deviation of the residuals of monthly ablation between the daily and hourly models was $0.4 \mathrm{~cm}$ weq, suggesting that adjusting $\chi$ alone accounts for the difference in time step. Because the agreement between the daily and hourly models was so high, we feel justified using a daily time step to model a process that likely occurs over shorter timescales; while melt and ablation may perhaps be calculated incorrectly for individual days, seasonal totals seem robust. This is important because the significant savings in computational speed of using the daily model will be important in our future studies applying the model in a spatially distributed fashion.

\section{Results and Analysis}

\subsection{Model Performance}

[16] Modeled ablation compares well to seasonal (winter, summer) measurements (Figure 4), as expected because the

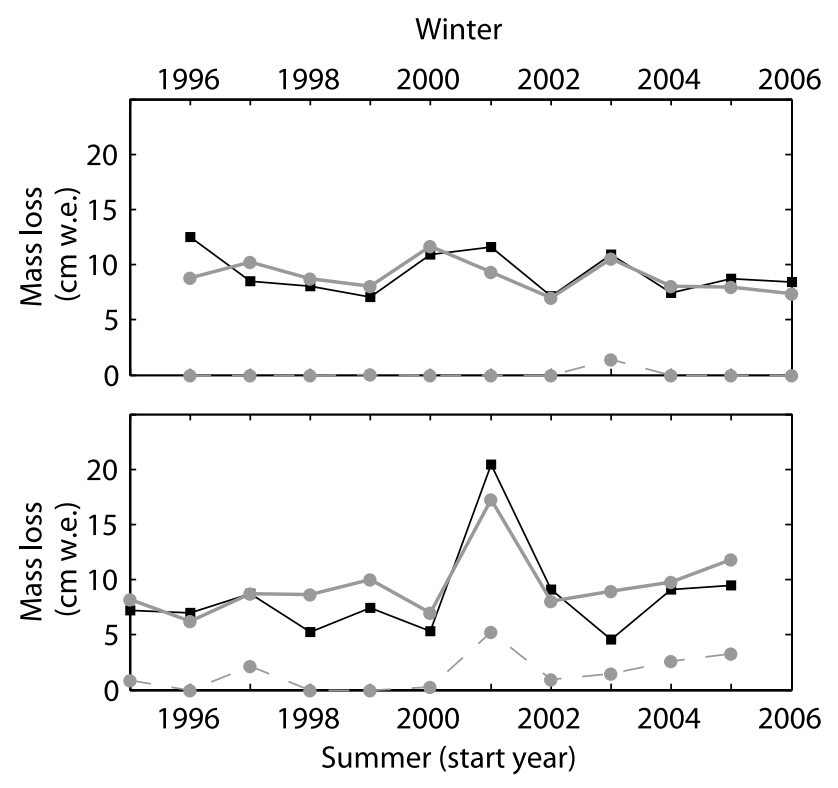

Figure 4. Measured (black line) and modeled (gray line) ablation and melt (dashed line) for each season. 


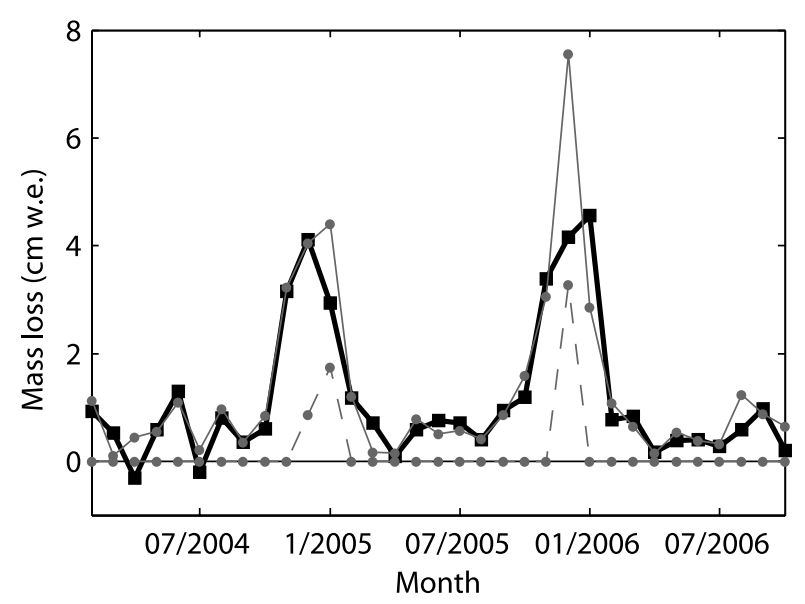

Figure 5. Measured (black line) and modeled (gray line) ablation and melt (dashed line) for each month that the ultrasonic distance sensor was operational.

model is calibrated to ablation. The model performs better in winter $(\mathrm{RMSE}=1.5 \mathrm{~cm}$ weq) than in summer $(\mathrm{RMSE}=$ $2.3 \mathrm{~cm}$ weq), probably due to the different heat required to sublimate versus melt ice. Sublimation requires eight times more energy to ablate the same ice mass as melting, and errors in the energy balance near the warmest time of the year may be the reason why there are more summers than winters with sizable residuals. At the monthly intervals, the model also compares well to measurements, but large errors in December and January of the 2005-2006 summer (Figure 5) are presumably due to errors in calculating melt. These errors offset one another, suggesting that the model predicts summer totals better than ablation at shorter timescales.

[17] Unlike ablation, measured ice temperatures provide an independent test of the model. Comparison of modeled and measured ice temperatures, spanning significant portions of 8 different model years, shows that the model captures ice temperature magnitudes and variations across the range of depths sufficiently to provide confidence in model accuracy (Figure 6). Quantitative comparisons are precluded, however, because summer radiative heating of the thermistors exceeds that of the surrounding ice, causing the measured temperature to be warmer than the true ice temperature [e.g., Brandt and Warren, 1993; Liston et al., 1999]. Second, thermistor depth is only known accurately when installed, and estimated thermistor depth using ablation measurements becomes less accurate with time. Therefore, we expect measured temperatures to be a little warmer than modeled in summer but identical in winter, as is the case, and the fit between the modeled and measured ice temperatures decreases with time since installation, also shown in the data. Moreover, ice temperatures within $1 \mathrm{~m}$ of the surface are strongly affected by radiative heating, and close correspondence with modeled temperatures supports our choice of effective grain radius and solar radiation partition coefficient. We acknowledge that accurately calculated ice temperatures may not necessarily be a powerful constraint on the surface energy balance since the conduction term is typically a minor contribution to the surface energy balance. However, we believe that they provide a meaningful check on our calculation of subsurface melting, particularly since we are unable to make direct long-term, quantitative observations of subsurface melting.

[18] The magnitude of $\chi$ determined through calibration indicates that the majority of the net solar radiation $(82 \%)$ is absorbed at the surface. Despite the large percentage absorbed at the surface, including the solar-radiation transmission into the ice in the model provided a much better fit than using a "traditional" energy balance approach where $100 \%$ of net solar radiation is included in the surface energy balance. Eliminating the source term leaves $z_{0}$ as the only calibration parameter, and the minimum RMSE in seasonal ablation becomes $4.35 \mathrm{~cm}$, using $z_{0}=0.50 \mathrm{~mm}$. With the traditional approach, the total ablation of all 11 summer seasons is overestimated by more than $50 \%$, regardless of choice of $z_{0}$. These results suggest that accounting for the absorption of a significant portion of the net solar radiation below the ice surface greatly improves our ability to model

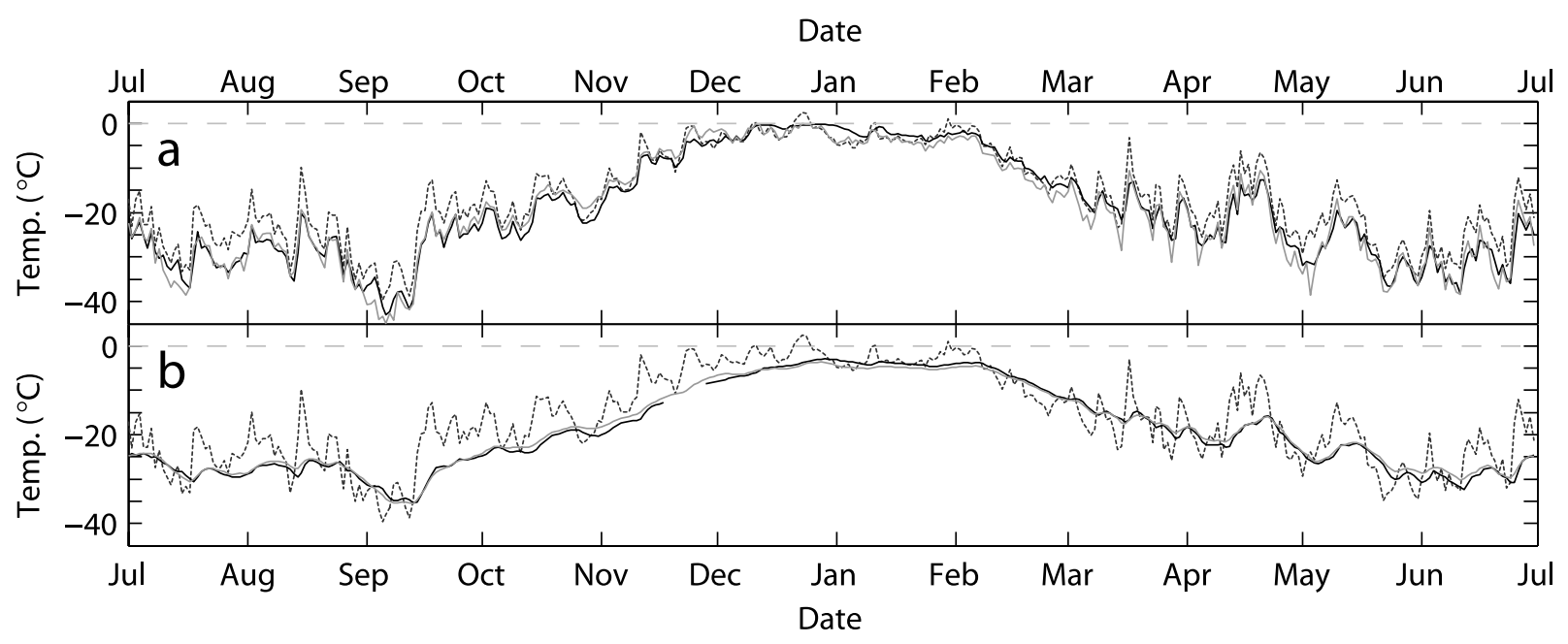

Figure 6. Measured (black line) and modeled (gray line) ice temperature and measured air temperature (dashed line) during model year 1995 for (a) the shallow thermistor (depth ablated from $12 \mathrm{~cm}$ to surface during this time period) and (b) the deep thermistor (depth ablated from 92 to $78 \mathrm{~cm}$ ). 


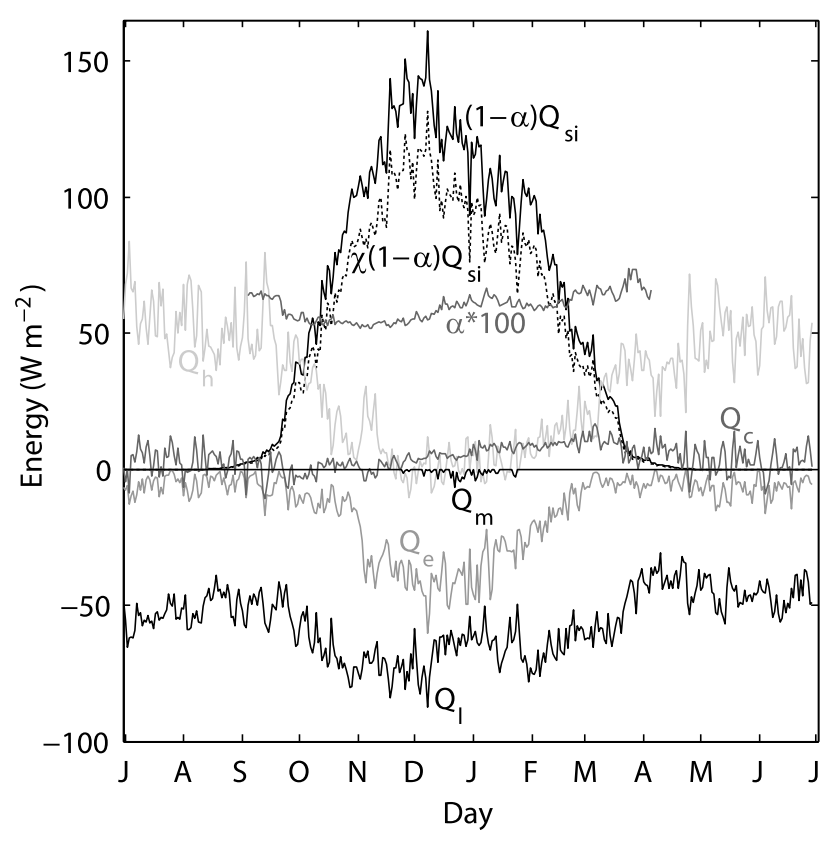

Figure 7. Average daily energy balance components for the 11 model years (July 1995 to June 2006).

the energy balance on the snow-free glacier ablation zones of the MDV. We must acknowledge the alternative explanations of a systematic overheating of the surface by the model during the summer or a bias in our meteorological measurements. However, our interpretation is supported by modeled ice temperatures at $\sim 85 \mathrm{~cm}$ being $\sim 3^{\circ} \mathrm{C}$ too low throughout summer but accurate during winter using the traditional approach, while being a good match $\left( \pm 0.5^{\circ} \mathrm{C}\right)$ to measured ice temperatures year-round when we include the solar-radiation source term.

\subsection{Energy Balance}

[19] The average daily energy balance over the eleven modeled years (1995-2006) shows that during the austral winter (April-September), net longwave radiation, $Q_{l}$, is the largest energy loss, $\sim-55 \mathrm{~W} \mathrm{~m}^{-2}$, while sensible heat, $Q_{h}$, provides the largest energy gain to the surface, $\sim+60 \mathrm{~W} \mathrm{~m}^{-2}$ (Figure 7). Latent heat, $Q_{e}$, is comparatively small, $\sim-10 \mathrm{~W} \mathrm{~m}^{-2}$, indicating low sublimation rates as confirmed by the ablation measurements. Conduction between the subsurface and the surface, $Q_{c}$, generally provides energy to the surface, $<+15 \mathrm{~W} \mathrm{~m}^{-2}$, but during warm katabatic events, it is an energy sink.

[20] During austral summer (October-March), net shortwave radiation is the dominant source of energy to the ice, up to $\sim+140 \mathrm{~W} \mathrm{~m}^{-2}$, as expected. Its temporal distribution shows the expected bell shape curve, peaking at solstice, but with a pronounced drop in midsummer because of an increase in ice albedo. Our field observations indicate that the albedo increase is due to a noticeable brightening of the ice from blue-gray to white. This increase does not occur in all years. $Q_{l}$ becomes slightly more negative compared to winter, $\sim-70 \mathrm{~W} \mathrm{~m}^{-2}$, and $Q_{h}$ is small, $<\sim+20 \mathrm{~W} \mathrm{~m}^{-2}$, and generally remains positive. $Q_{e}$ approaches $\sim-50 \mathrm{~W} \mathrm{~m}^{-2}$ during midsummer as sublimation rates increase almost an order of magnitude from winter rates, becoming almost as large an energy loss as $Q_{l} . Q_{c}$ increases steadily from near zero at the start of summer to a peak of $\sim+15 \mathrm{~W} \mathrm{~m}^{-2}$ in late summer and represents subsurface heating by solar radiation in the top $50 \mathrm{~cm}$ of the ice. Ice temperatures in the upper $50 \mathrm{~cm}$ typically range from -50 to $-20^{\circ} \mathrm{C}$ in winter, with brief warmer periods caused by katabatic events. In summer, ice temperatures are less variable, typically between -5 and $0^{\circ} \mathrm{C}$, because air temperature is less variable and heat stored in the ice from solar radiation helps to buffer against surface losses. Melting occurs infrequently and is a minor component of the energy balance, $>\sim-5 \mathrm{~W} \mathrm{~m}^{-2}$.

\subsection{Ablation and Surface Melt}

[21] Ablation during the $\sim 10$ month winter varies between 7 and $13 \mathrm{~cm}$ weq, while ablation during the $\sim 2$ month summer varies between 4 and $10 \mathrm{~cm}$ weq, with one summer (2001-2002) reaching $21 \mathrm{~cm}$ weq On average, the mid-November to late January summer period accounts for nearly $50 \%$ of annual ablation. For the 2.5 years over which continuous surface elevation change was measured, both the measurements and modeling indicate that a distinct summer season lasts from November to January (Figure 5). The largest average monthly ablation rate occurs in December $\left(1.6 \mathrm{~mm}\right.$ weq $\left.\mathrm{d}^{-1}\right)$. The winter season from late February to October is characterized by low ablation rates $(0.24 \mathrm{~mm}$ weq $\mathrm{d}^{-1}$ ) and high month-to-month variability. Winter katabatic events play an important role in increasing sublimation; causing $50 \%$ of the sublimation during May-August to occur on $10 \%$ of the days.

[22] Of the 11 years modeled, surface melting occurred for a total of 42 days in 9 of the 11 years, yielding an average daily rate of $0.4 \mathrm{~cm}$ weq and average annual rate of $1.7 \mathrm{~cm}$ weq (Table 2). The melt events occurred between 26 November and 24 January. No temporal pattern exists for the modeled melt events, except that events in early/late summer tended to be smaller. Even during the "flood year" (2001-2002) [Doran et al., 2008; Foreman et al., 2004] when air temperatures at Taylor Glacier were above freezing for about three weeks, sublimation accounted for the majority of summer ablation on Taylor Glacier.

[23] Modeled melt events occurred on warm ( -2.7 to $\left.+3.4^{\circ} \mathrm{C}\right)$ days with low wind speeds $\left(\right.$ mean $\left.=3.6 \mathrm{~m} \mathrm{~s}^{-1}\right)$ and moderate to high incoming solar radiation $\left(190-387 \mathrm{~W} \mathrm{~m}^{-2}\right.$ ). Twenty melt days (48\%) occurred when daily air temperatures were below freezing. In contrast, no melt occurred on 48 of 67 days $(72 \%)$ with air temperatures above freezing. Most warm days are associated with katabatic winds resulting in high latent heat fluxes that suppress melt. Because average daily temperature was rarely warmer than $2^{\circ} \mathrm{C}$, low wind speed seems to be critical for surface melt; 32 of $42(76 \%)$ melt days occurred during winds $<4.0 \mathrm{~m} \mathrm{~s}^{-1}$. Six of the melt days (14\%) seem to result from "radiation paradox" conditions [Wendler, 1986] when cloud cover results in a gain in longwave radiation that more than compensates for the reduction in shortwave radiation. On days with melt, the average latent and sensible heat flux have smaller magnitudes than for the summer as a whole, whereas net radiation is much larger (Table 3 ).

\subsection{Subsurface Melt}

[24] According to our model, subsurface melting occurred in ten of eleven summers, often without surface melt, and 
Table 2. Summary of Surface and Subsurface Melt for All Melt Seasons

\begin{tabular}{|c|c|c|c|c|c|c|c|c|c|}
\hline \multirow[b]{2}{*}{ Season } & \multicolumn{2}{|c|}{ Surface Melt } & \multicolumn{3}{|c|}{ Subsurface Melt } & \multicolumn{4}{|c|}{ December-January Average Meteorological Data } \\
\hline & $\begin{array}{c}\text { Depth } \\
\text { (cm weq) }\end{array}$ & $\begin{array}{c}\text { Number of } \\
\text { Days }\end{array}$ & $\begin{array}{c}\text { Maximum Water } \\
\text { Column Depth }(\mathrm{cm})\end{array}$ & $\begin{array}{c}\text { Depth } x \\
\text { Duration }\left(\mathrm{cm} \mathrm{d}^{-1}\right)\end{array}$ & $\begin{array}{l}\text { Number of } \\
\text { Days }\end{array}$ & $\mathrm{T}\left({ }^{\circ} \mathrm{C}\right)$ & $Q_{s i}\left(\mathrm{~W} \mathrm{~m}^{-2}\right)$ & RH (\%) & Wind $\left(\mathrm{m} \mathrm{s}^{-1}\right)$ \\
\hline $1995-1996$ & 0.9 & 2 & 0.02 & 0.04 & 2 & -2.5 & 285.9 & 60.5 & 4.3 \\
\hline $1996-1997$ & 0.0 & 0 & 0.05 & 0.07 & 3 & -2.6 & 266.6 & 58.6 & 4.1 \\
\hline $1997-1998$ & 2.2 & 5 & 0.09 & 0.19 & 4 & -4.3 & 277.4 & 67.7 & 4.1 \\
\hline $1998-1999$ & 0.0 & 1 & 0.04 & 0.08 & 2 & -2.7 & 292.5 & 56.0 & 4.7 \\
\hline $1999-2000$ & 0.0 & 0 & 0.01 & 0.02 & 2 & -3.4 & 296.4 & 53.5 & 4.3 \\
\hline $2000-2001$ & 0.2 & 1 & 0.00 & 0.00 & 0 & -4.5 & 307.1 & 63.8 & 4.5 \\
\hline $2001-2002$ & 5.3 & 13 & 1.65 & 34.44 & 39 & -1.6 & 299.2 & 55.4 & 5.2 \\
\hline $2002-2003$ & 2.4 & 5 & 0.35 & 2.97 & 19 & -3.3 & 287.3 & 66.7 & 4.3 \\
\hline $2003-2004$ & 1.4 & 3 & 0.58 & 4.10 & 15 & -3.4 & 304.1 & 65.2 & 4.2 \\
\hline $2004-2005$ & 2.6 & 7 & 0.15 & 0.89 & 16 & -2.5 & 273.9 & 63.8 & 4.0 \\
\hline $2005-2006$ & 3.3 & 5 & 0.41 & 3.67 & 29 & -2.6 & 294.5 & 62.7 & 4.2 \\
\hline Average & 1.7 & 3.8 & 0.30 & 4.22 & 11.9 & -3.0 & 289.5 & 61.3 & 4.4 \\
\hline
\end{tabular}

occurred at depths of $0-50 \mathrm{~cm}$. During predicted surface melt periods, subsurface melt was present $79 \%$ of the time, and less ice melted in the subsurface than at the surface. Overall, subsurface melt was present about three times more often than surface melt (Table 2), and the subsurface was actively melting (positive subsurface melt flux) twice as often as the surface. Subsurface melt was present during the warmest summer, 2001-2002, subsurface melt was modeled continuously at depths $>30 \mathrm{~cm}$ for nearly six weeks and the partially melted layer spanned $50 \mathrm{~cm}$ in thickness. However, even in the warmest summer, subsurface melt never exceeded $8 \%$ by mass (Figure 8). Subsurface melt was predicted to be present over a wide range of conditions - at air temperatures as low as $\sim-8^{\circ} \mathrm{C}$ and wind speeds as high as $15 \mathrm{~m} \mathrm{~s}^{-1}$. Total subsurface water expressed as a column of water varied dramatically between summers (Table 2); five summers exceed $0.1 \mathrm{~cm}$ and in the warmest summer (2001-2002) the maximum value is $1.6 \mathrm{~cm}$ (Figure 9).

[25] We have yet to deploy a practical method for systematically observing subsurface melt, but the good match between measured and modeled ice temperatures provides some confidence to our calculations of subsurface melt. Additionally, the modeled subsurface melt is consistent with our anecdotal observations that subsurface heating is not particularly important for melt within the white, bubbly ice of MDV glaciers. We have looked for subsurface melt on Taylor Glacier on days when we observed partial melting across the glacier surface. No subsurface melt was observed during repeated drilling of holes to $50 \mathrm{~cm}$ depth between the meteorological station and the terminus, except in cryoconite holes or debris-rich ice. We are uncertain if small fractions of partial melt along grain boundaries would be detectable during drilling, but the modeled maximum values of subsurface melt seem reasonable on the basis of our qualitative observations. In comparison, substantial liquid water has been observed in cryoconite holes (not modeled) when the surrounding glacier surface and subsurface appear dry [Fountain et al., 2004].

\section{Discussion}

\subsection{Energy Balance}

[26] Within Taylor Valley, and the MDV in general, ablation is quite variable at many spatial scales. On decimeter scales, ablation varies because of albedo variations imposed by patches of snow and sediment. On scales of $\sim 10 \mathrm{~m}$, ablation changes dramatically because of topographic roughness that generates microclimates, most important of which is reduced wind speed [Johnston et al., 2005; Lewis et al., 1999]. Under these conditions, the energy balance shifts to favor melting over sublimation because of the suppression of the heat losses to the turbulent fluxes, anecdotally observed since the early explorers [Taylor, 1916]. Therefore, our discussion here applies to the broad expanse of smooth and nearly level ice of Taylor Glacier and not to the interior of the deeply incised channels farther down glacier, the occasional hollows found on the glacier surface, or the terminal cliffs.

Table 3. Average Energy Balance Components ${ }^{\mathrm{a}}$

\begin{tabular}{|c|c|c|c|c|}
\hline & Annual & Summer $^{\mathrm{b}}$ & Days With Melt & Days With Positive Subsurface Flux \\
\hline Net shortwave $\left(\mathrm{W} \mathrm{m}^{-2}\right)$ & 43.8 & 116.4 & 140.9 & 140.1 \\
\hline Net shortwave surface $\left(\mathrm{W} \mathrm{m}^{-2}\right)$ & 35.8 & 95.1 & 115.1 & 114.5 \\
\hline Net shortwave subsurface $\left(\mathrm{W} \mathrm{m}^{-2}\right)$ & 8.0 & 21.3 & 25.8 & 25.6 \\
\hline Incoming longwave $\left(\mathrm{W} \mathrm{m}^{-2}\right)$ & 175.7 & 229.7 & 244.8 & 236.5 \\
\hline Outgoing longwave $\left(\mathrm{W} \mathrm{m}^{-2}\right)$ & -232.3 & -295.4 & -309.3 & -307.9 \\
\hline Net longwave $\left(\mathrm{W} \mathrm{m}^{-2}\right)$ & -56.6 & -65.7 & -64.5 & -71.4 \\
\hline Net radiation $\left(\mathrm{W} \mathrm{m}^{-2}\right)$ & -12.8 & 50.7 & 76.4 & 68.7 \\
\hline Net radiation surface $\left(\mathrm{W} \mathrm{m}^{-2}\right)$ & -20.8 & 29.4 & 50.6 & 43.1 \\
\hline Sensible heat $\left(\mathrm{W} \mathrm{m}^{-2}\right)$ & 31.5 & 2.6 & 1.8 & 4.3 \\
\hline Latent heat $\left(\mathrm{W} \mathrm{m}^{-2}\right)$ & -14.8 & -37.3 & -36.4 & -44.5 \\
\hline Turbulent heat $\left(\mathrm{W} \mathrm{m}^{-2}\right)$ & 16.7 & -34.7 & -34.6 & -40.2 \\
\hline Conduction $\left(\mathrm{W} \mathrm{m}^{-2}\right)$ & 4.2 & 6.3 & 0 & 3.8 \\
\hline $\operatorname{Melt}\left(\mathrm{W} \mathrm{m}^{-2}\right)$ & -0.2 & -1.0 & -16.8 & -7.4 \\
\hline
\end{tabular}

${ }^{\mathrm{a}}$ Positive values indicate transport toward the surface.

${ }^{\mathrm{b}}$ Here summer is from December to January. 


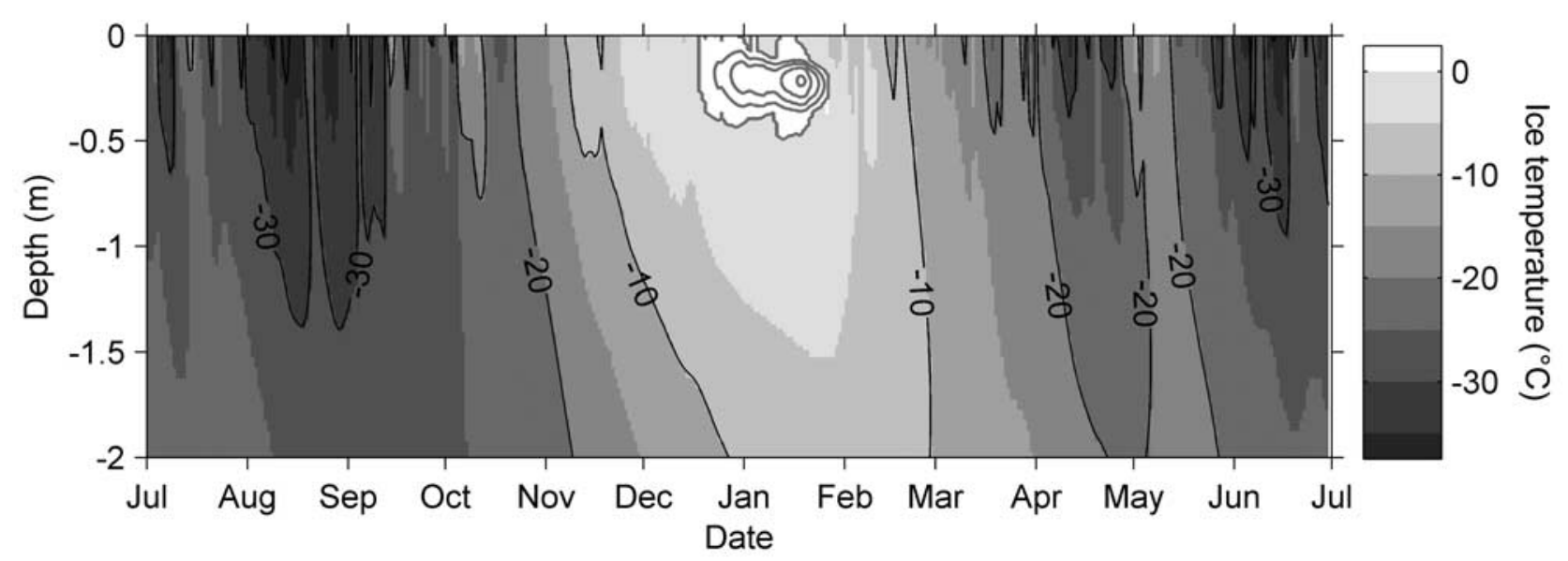

Figure 8. Ice temperature and meltwater fraction (2\% water fraction contours in gray) for 2001-2002.

[27] Over the entire year, solar radiation $\left(+44 \mathrm{~W} \mathrm{~m}^{-2}\right)$ and sensible heat $\left(+32 \mathrm{~W} \mathrm{~m}^{-2}\right)$ provide most energy to the glacier, $55 \%$ and $40 \%$, respectively, while most energy is lost to longwave radiation $\left(-57 \mathrm{~W} \mathrm{~m}^{-2}\right)$ and latent heat $\left(-15 \mathrm{~W} \mathrm{~m}^{-2}\right), 79 \%$ and $21 \%$, respectively (Table 3$)$. These annual values differ somewhat from other Antarctic sites where energy balance modeling has also included internal heating by transmission of solar radiation within the glacier ice. For blue ice at Svea, Dronning Maud Land, Bintanja et al. [1997] found similar radiation magnitudes, but the turbulent fluxes at Taylor Glacier are each three times larger in magnitude, possibly because of larger surface roughness. For blue ice at Jutulgryta, Dronning Maud Land, Liston et al. [1999] report similar magnitudes of shortwave radiation and latent heat, but with one-third the losses to longwave radiation and a slightly negative sensible heat flux. All of the terms of the annual energy balance of Antarctic snow have the same sign as at Taylor Glacier, but generally have much smaller magnitude [e.g., Liston et al., 1999; Reijmer et al., 1999].

[28] The summer (defined here as December-January) energy balance (Table 3) is similar to other glaciers in Taylor Valley [Johnston et al., 2005; Lewis et al., 1998] and at blue ice areas [Bintanja and Van Den Broeke, 1995b; Wendler et al., 1988], but latent heat loss is much larger at Taylor Glacier than the other sites. The Taylor Glacier surface is generally cooler than the air (positive sensible heat flux), despite the subsurface heating of the ice. This contrasts with the blue ice at Svea, but is similar to the snow [Bintanja and Van Den Broeke, 1995b]. The average summer conductive flux at Taylor Glacier $\left(+6 \mathrm{~W} \mathrm{~m}^{-2}\right)$ is greater than that for snow $\left(+5 \mathrm{~W} \mathrm{~m}^{-2}\right)$ but smaller than that for blue ice at Svea $\left(+19 \mathrm{~W} \mathrm{~m}^{-2}\right)$ [Bintanja and Van Den Broeke, 1995b], suggesting subsurface scattering of solar radiation on Taylor Glacier ice is between that for blue ice and snow. Melt is less than $1 \%$ of the energy lost, and the conditions favorable for melt on Taylor Glacier (large radiation flux, smaller turbulent fluxes, Table 3) mirror conditions in the microclimate of basins and channels on MDV glaciers that generate enhanced melt [Chinn, 1987; Johnston et al., 2005; Lewis et al., 1999]. Interestingly, the energy balance of the tropical Kibo Northern Ice Field on Mount Kilimanjaro, $5794 \mathrm{~m}$ asl [Mölg and Hardy, 2004], is a close analog to the
Taylor Glacier summer energy balance. During a 7 month period of low snow cover at Kibo, all of the energy balance terms are of same sign as and similar magnitude to the summer energy balance at Taylor Glacier, but with more melt energy at Kilimanjaro, $-16 \mathrm{~W} \mathrm{~m}^{-2}$ versus $-1 \mathrm{~W} \mathrm{~m}^{-2}$. The ice surface roughness element shape of the glaciers is also similar [Mölg and Hardy, 2004], as well as the morphology, with near-flat horizontal glacier surfaces and vertical ice cliffs forming the glacier margins.

[29] The energy balance for days that the model calculates surface melt (Table 3) is similar to the summer (December-January) average, except with significantly greater $(+21 \%)$ net shortwave radiation and a relatively large fraction of the energy lost because of melting (14\% on melt days, $1 \%$ for summer average). The increase in average solar radiation absorbed at the surface on melt days $\left(20 \mathrm{~W} \mathrm{~m}^{-2}\right)$ is nearly balanced by the increase in energy lost to melting $\left(16 \mathrm{~W} \mathrm{~m}^{-2}\right)$. This suggests that solar radiation drives melt, provided the ice surface reaches the melting temperature. A 10\% increase in net solar radiation (either by decreased cloudiness or decreased albedo) under these conditions could approximately double the quantity of melt. Similarly, a $10 \%$ reduction in the turbulent fluxes on days

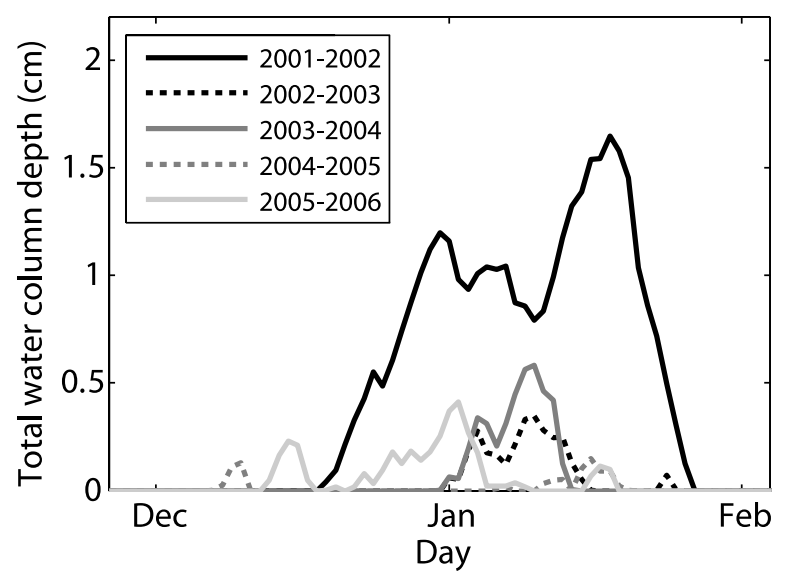

Figure 9. Total water column depth for summers with a maximum total water column depth greater than $0.1 \mathrm{~cm}$. 
with melt could increase the melt by $20 \%$. While the sensitivity of the energy balance is not as simple as this, this demonstrates how Taylor Glacier only marginally crosses the threshold of melt in summer, and modest increases of energy to the surface could increase melt substantially. As expected, days on which the subsurface was actively melting (positive subsurface melt flux) were characterized by high absorbed solar radiation and slightly larger turbulent fluxes than on days with surface melt (Table 3).

[30] The momentum surface roughness determined by calibration of the model $(2.5 \mathrm{~mm})$ is 2 orders of magnitude larger than that estimated for blue ice by measured wind speed profiles $(0.003 \mathrm{~mm})$ [Bintanja and Van Den Broeke, $1995 \mathrm{a}]$. Our calibration roughness value is consistent with occasional melting that roughens the ice in ways that are not aerodynamically efficient [Bintanja, 1999]. Blue ice, as defined by Bintanja [1999], is not influenced by melt and may be the smoothest permanent, natural surface. On the basis of the summary of measured aerodynamic roughness lengths compiled by Brock et al. [2006], our calibrated value at Taylor Glacier is greater than Antarctic blue ice and Arctic "smooth" ice $(0.007-0.17 \mathrm{~mm})$, but smaller than typical Arctic ice subject to melting $(0.6-6.7 \mathrm{~mm})$. Therefore, our calibrated roughness is consistent with occasionally melting glacier ice. However, the roughness on Taylor and other glaciers in the MDV is probably not constant because of the roughness elements that begin to form by the occasional melt events being erased by $\sim 10 \mathrm{~cm}$ weq of sublimation in winter. If this effect is indeed significant, our assumption of a constant surface roughness may lead to errors in estimated turbulent fluxes and ablation.

\subsection{Ablation and Surface Melt}

[31] Our measurements and modeling of annual ablation over the 11 year period average $17.7 \mathrm{~cm} \mathrm{a}^{-1}$ weq and $18.4 \mathrm{~cm} \mathrm{a}^{-1}$ weq, respectively. In comparison, coastal blue ice at Reeves Glacier, Victoria Land, $26 \mathrm{~cm} \mathrm{a}^{-1}$ [Stearns and Weidner, 1993], and Sør Rondane Mountains, Dronning Maud Land, 20-28 $\mathrm{cm} \mathrm{a}^{-1}$ weq [Takahashi et al., 1992], are similar. Most other blue ice regions have lower ablation rates, 2-15 $\mathrm{cm} \mathrm{a}^{-1}$ weq [Bintanja, 1999; Genthon et al., 2007], as does Antarctic snow (1-10 $\mathrm{cm} \mathrm{a}^{-1}$ weq) [Stearns and Weidner, 1993]. Much of this variation is due to local climate conditions and ice albedo. About $9 \%$ of ablation on Taylor Glacier is caused by melt, a fraction intermediate among blue ice areas in Antarctica. Melting accounts for $15-30 \%$ of ablation elsewhere in MDV [Fountain et al., 1998], and may account for up to $39 \%$ of ablation on coastal blue ice in Terre Adélie [Genthon et al., 2007]. True blue ice areas, as defined by Bintanja [1999], experience no melt and are typically found at higher and colder elevations on the ice sheets.

[32] The seasonal distribution of sublimation at Taylor Glacier is similar to other Antarctic ice locations. At Lake Hoare, $23 \mathrm{~km}$ away but still in Taylor Valley, $73 \%$ of the $35 \mathrm{~cm}$ of annual sublimation occurs during the 15 October to 1 April summer period [Clow et al., 1988], at Taylor Glacier 75\%. At Svea, Dronning Maud Land (1170 m asl), 71\% of the $14 \mathrm{~cm}$ of annual sublimation occurred during the summer (November-February) [Bintanja and Reijmer, 2001], similar to $69 \%$ at Taylor Glacier for the same period.
[33] Surface melt was estimated to occur on only 42 days over the 11 year period of study, supporting anecdotal observations of the paucity of melt and the relatively low runoff from Taylor Glacier, despite being the largest glacier in the valley. In comparison to Canada Glacier, $24 \mathrm{~km}$ down valley toward the coast, during the 1995-1996 summer Taylor Glacier had $0.87 \mathrm{~cm}$ weq of melt compared to Canada, which had $4.46 \mathrm{~cm}$ weq [Lewis et al., 1998]. Air temperatures between the sites were similar and averaged around $-2.5^{\circ} \mathrm{C}$, and the primary difference was wind speed $\left(4.3 \mathrm{~m} \mathrm{~s}^{-1}\right.$ at Taylor versus $2.9 \mathrm{~m} \mathrm{~s}^{-1}$ at Canada) that caused the latent heat flux at Taylor Glacier $\left(-37 \mathrm{~W} \mathrm{~m}^{-2}\right)$ to be $17 \mathrm{~W} \mathrm{~m}^{-2}$ larger than at Canada Glacier $\left(-20 \mathrm{~W} \mathrm{~m}^{-2}\right)$. Summer katabatic winds occur twice as often at Taylor Glacier as Canada Glacier [Nylen et al., 2004]. Also affecting the latent flux, the surface roughness used by Lewis et al. [1998], $1 \times 10^{-4} \mathrm{~m}$, is the same order of magnitude but half as small as we use at Taylor. This rough comparison of different modeling results suggests that a reduction in wind speed at Taylor Glacier comparable to what is experienced elsewhere in the valley could increase melt fivefold. The sensitivity of melt on Taylor Glacier to wind speed may not be as simple as this, as a reduction in katabatic events would also reduce the associated higher temperatures, but this example demonstrates how small changes in the meteorological conditions on MDV glaciers can cause large changes in melt and the resulting streamflow.

[34] Our results contrast strongly with Johnston et al. [2005] who calculated $3.4 \mathrm{~cm}$ weq of melt at Taylor Glacier for the 1994-1995 summer, an extremely large value compared to our estimates over the 11 years, and contrasts with the relatively low melt summer that year at Canada Glacier [Lewis et al., 1998], despite similar air temperatures. We suspect the problem may be the transfer coefficient method Johnston et al. [2005] used for calculating turbulent fluxes, which appears to underestimate latent heat flux. Johnston et al. [2005] estimated the summer average latent heat at $-22 \mathrm{~W} \mathrm{~m}^{-2}$, the same value estimated for Canada Glacier [Lewis et al., 1998] despite wind speeds 40\% higher at Taylor Glacier. While the transfer coefficient method may provide satisfactory results for relative melt rates between the flat surface and incised channels, the purpose of Johnston's study, our approach provides more robust values of sublimation and melt, given our use of 22 seasonal measurements for model calibration.

[35] The ability of the model to reasonably predict surface melt is important for our future application to predict stream flow. Using daily time steps, however, may underestimate surface melt. We compared daily and hourly time step models for the 2005-2006 summer, and the daily model predicts $3.3 \mathrm{~cm}$ weq surface melt (28\% of summer ablation) for 5 days when melt occurred, while the hourly model predicts $5.7 \mathrm{~cm}$ weq (48\% of ablation) occurring over 29 days in which melt occurred. Expressing the results differently, the hourly model produces $40 \%$ of the seasonal surface melt in the same 5 days that the daily model predicts $100 \%$ of the seasonal surface melt, suggesting that the daily model is capturing only the most significant surface melt days. The reason may be that the summer energy balance is typically close to producing melt, and transient excursions that momentarily produce melt are suppressed within the daily average values of the meteorological conditions. However, we have observed such transient conditions and 
witnessed ice melt being generated for an hour or so. The melt occurs in patches on the glacier surface and these thin pools do not flow significant distances $(\sim<10 \mathrm{~m})$ before refreezing (Figure 2). In some cases, it was unclear whether the water froze because of its migration into a less favorable microclimate or temporal meteorological conditions changed. We hypothesize that only the most significant melt days constitute runoff, whereas the smaller transient melt events captured by the hourly model do not.

\subsection{Subsurface Melt}

[36] Comparisons between subsurface melt at Taylor Glacier and other locations are more difficult because few studies calculate subsurface melt and methods vary. Bintanja and Van Den Broeke [1995b] did not observe or model subsurface melting at the blue ice region of Svea, but did model "occasional" subsurface temperatures of $0^{\circ} \mathrm{C}$. Subsurface melting has been observed at depths up to $1 \mathrm{~m}$ in the blue ice of Jutulgryta, Dronning Maud Land [Winther et al., 1996], and Liston et al. [1999] calculated that melting may occur up to $1.7 \mathrm{~m}$ deep, with a maximum melt fraction of $25 \%$. Our calculations for Taylor Glacier show melting occurs at depths half that as Jutulgryta and much lower melt fractions, $0.5 \mathrm{~m}$ and $<10 \%$ respectively. Instead, modeled subsurface melt depth and water fraction at Taylor Glacier are more similar to that calculated for snow at Jutulgryta, $0.75 \mathrm{~m}$ and 4\%, respectively [Liston et al., 1999]. Indeed, the grain radius we employ is smaller than Liston et al. [1999] used for the snow, suggesting that the scattering properties of ice at Taylor Glacier (grain radius, density, and void size) are more similar to that of snow than blue ice. Exceptions on Taylor Glacier include cryoconite holes and refrozen fractures, which have a $20 \%$ lower albedo [Lewis, 2001] and less bubbly ice, more similar to blue ice. Indeed, we commonly observe surface melt in the holes and refrozen fractures [Fountain et al., 2004]. We conclude that subsurface melt is only common where debris melts into the ice (forming cryoconite holes) and lowers the albedo through the presence of dark sediment and clearer ice and where refrozen fractures produce less bubbly ice, and together comprise the bulk of the subsurface meltwater in Taylor Glacier. This contrasts with the results of Liston et al. [1999] who found widespread subsurface melting.

\section{Conclusions}

[37] The energy balance model based on Liston et al. [1999] performed well in estimating both the ablation and ice temperatures over the 11 year record on Taylor Glacier. The inclusion of solar-radiation transmission into the ice significantly improves model performance over a traditional energy balance approach. The daily melt model captures the large melt events but in comparison to the hourly model it misses melt events of shorter timescales. The conditions on the glacier surface are on the threshold of melting and using daily average meteorological variables essentially masks the high-frequency transient conditions that may produce melt. However, these transient events are unlikely to produce runoff from regions like that around the meteorological station on Taylor Glacier because field observations suggest that they flow for short distances before refreezing.
[38] Results confirm previous studies that Taylor and other glaciers in the MDV are dominated by sublimation in all seasons and surface melt is a significant contribution only during some summers. Surface melt does not typically occur at our study site on Taylor Glacier. Its occurrence requires low wind speeds, and air temperatures near freezing. Positive air temperatures are neither necessary for nor a reliable indicator of surface melt. The windy conditions at Taylor Glacier suppress melt while it occurs elsewhere in the MDV where winds are calmer.

[39] According to the model, while daily surface melt is usually accompanied by subsurface melt, the reverse is not true, and little correspondence exists from season to season between the magnitudes of the two. Subsurface melt is generally small (never exceeding $2 \mathrm{~cm}$ weq) and is completely absent in some years. Both the energy balance and magnitude of subsurface melting indicate that Taylor Glacier is composed of "white" ice, intermediate in optical properties between snow and blue ice.

[40] We conclude that the energy balance in the MDV environment is on the threshold of generating substantial melt. Small changes in the balance can produce significant increases in melt on the surface and in the subsurface. Reduction of wind speed and increases in absorbed solar radiation create favorable conditions for melt. This is observed in topographic basins, and vertical cliffs can experience 8 times as much ablation as horizontal surfaces [Chinn, 1987] and can contribute disproportionate amounts of meltwater relative to their area [Lewis et al., 1999]. Also small changes in albedo, due to bubbles in the ice or sediment (not explored here) can also shift the energy balance more favorably toward melt. This is observed in cryoconite holes and refrozen fractures. Although they represent a small area of the surface of MDV glaciers, they are a potentially important source of meltwater [Fountain et al., 2004]. The model summarized here has the ability to accommodate these spatial variations in topography and ice properties such that we are optimistic in our future ability to accurately predict glacial runoff.

[41] Acknowledgments. This work was funded by the National Science Foundation, Office of Polar Programs, grants ANT-0423595 and ANT-0233823. We thank Hassan Basagic for assistance in the field and Jon Ebnet for initial application of the model to Taylor Valley. Reviews by Richard Bintanja, Faron Anslow, and an anonymous reviewer helped to improve the manuscript.

\section{References}

Bintanja, R. (1999), On the glaciological, meteorological, and climatological significance of Antarctic blue ice areas, Rev. Geophys., 37, 337-359, doi:10.1029/1999RG900007.

Bintanja, R., and C. H. Reijmer (2001), Meteorological conditions over Antarctic blue-ice areas and their influence on the local surface mass balance, J. Glaciol., 47, 37-50, doi:10.3189/172756501781832557.

Bintanja, R., and M. R. Van Den Broeke (1995a), Momentum and scalar transfer coefficients over aerodynamically smooth Antarctic surfaces, Boundary Layer Meteorol., 74(1-2), 89-111, doi:10.1007/BF00715712. Bintanja, R., and M. R. Van Den Broeke (1995b), The surface energy balance of Antarctic snow and blue ice, J. Appl. Meteorol., 34(4), 902-926, doi:10.1175/1520-0450(1995)034<0902:TSEBOA>2.0.CO;2.

Bintanja, R., S. Jonsson, and W. H. Knap (1997), The annual cycle of the surface energy balance of Antarctic blue ice, J. Geophys. Res., 102(D2), 1867-1881, doi:10.1029/96JD01801

Bomblies, A. (1998), Climatic controls on streamflow from Antarctic glaciers, M.S. thesis, 110 pp., Univ. of Colo., Boulder.

Brandt, R. E., and S. G. Warren (1993), Solar-heating rates and temperature profiles in Antarctic snow and ice, J. Glaciol., 39(131), 99-110. 
Brock, B. W., I. C. Willis, and M. J. Sharp (2006), Measurement and parameterization of aerodynamic roughness length variations at Haut Glacier d'Arolla, Switzerland, J. Glaciol., 52, 281-297, doi:10.3189/ 172756506781828746 .

Brutsaert, W. (1982), Evaporation Into the Atmosphere: Theory, History, and Applications, 299 pp., Kluwer Acad., Dordrecht, Netherlands.

Chinn, T. J. H. (1981), Hydrology and climate in the Ross Sea area, J. $R$. Soc. N. Z., 11(4), 373-386.

Chinn, T. J. H. (1987), Accelerated ablation at a glacier ice-cliff margin, Dry Valleys, Antarctica, Arct. Alp. Res., 19(1), 71-80, doi:10.2307/ 1551002.

Clow, G. D., C. P. McKay, G. M. Simmons, and R. A. Wharton (1988), Climatological observations and predicted sublimation rates at Lake Hoare, Antarctica, J. Clim., 1, 715-728, doi:10.1175/15200442(1988)001<0715:COAPSR >2.0.CO;2.

Dana, G. L. and R. A. Wharton Jr. (1998), Solar radiation in the McMurdo Dry Valleys, Antarctica, in Ecosystem Dynamics in a Polar Desert: The McMurdo Dry Valleys, Antarctica, Antarct. Res. Ser., vol. 72, edited by J. C. Priscu, pp. 39-64, AGU, Washington, D. C.

Dana, G. L., R. E. Davis, A. G. Fountain, and R. A. Wharton Jr. (2002), Satellite-derived indices of stream discharge in Taylor Valley, Antarctica, Hydrol. Processes, 16(8), 1603-1616, doi:10.1002/hyp.1024.

Doran, P. T., G. L. Dana, J. T. Hastings, and R. A. Wharton Jr. (1995), McMurdo Dry Valleys Long-Term Ecological Research (LTER): LTER automatic weather network (LAWN), Antarct. J. U. S., 1995 $276-280$.

Doran, P. T., C. P. McKay, G. D. Clow, G. L. Dana, A. G. Fountain, T. Nylen, and W. B. Lyons (2002), Valley floor climate observations from the McMurdo Dry Valleys, Antarctica, 1986-2000, J. Geophys. Res., 107(D24), 4772, doi:10.1029/2001JD002045.

Doran, P. T., C. P. McKay, A. G. Fountain, D. A. McKnight, and J. E. Barrett (2008), Hydrologic response to extreme warm and cold summers in the McMurdo Dry Valleys, east Antarctica, Antarct. Sci., 20, 499-509, doi:10.1017/S0954102008001272.

Drewry, D. J., S. R. Jordan, and E. Jankowski (1982), Measured properties of the Antarctic ice sheet: Surface configuration, ice thickness, volume, and bedrock characteristics, Ann. Glaciol., 3, 83-91.

Ebnet, A. F., A. G. Fountain, T. H. Nylen, D. M. McKnight, and C. Jaros (2005), A temperature-index model of stream flow at below-freezing temperatures in Taylor Valley, Antarctica, Ann. Glaciol., 40, 76-82, doi:10.3189/172756405781813519.

Foreman, C. M., C. F. Wolf, and J. C. Priscu (2004), Impact of episodic warming events, Aquat. Geochem., 10, 239-268, doi:10.1007/s10498004-2261-3

Fountain, A. G., G. L. Dana, K. J. Lewis, B. H. Vaughn, and D. M. McKnight (1998), Glaciers of the McMurdo Dry Valleys, southern Victoria Land, Antarctica, in Ecosystem Dynamics in a Polar Desert: The McMurdo Dry Valleys, Antarctica, Antarct. Res. Ser., vol. 72, edited by J. C. Priscu, pp. 65-75, AGU, Washington, D. C.

Fountain, A. G., et al. (1999), Physical controls on the Taylor Valley ecosystem, Antarctica, BioScience, 49(12), 961-971.

Fountain, A. G., M. Tranter, T. H. Nylen, K. J. Lewis, and D. R. Mueller (2004), Evolution of cryoconite holes and their contributions to meltwater runoff from glaciers in the McMurdo Dry Valleys, Antarctica, J. Glaciol., 50(168), 35-45, doi:10.3189/172756504781830312.

Fountain, A. G., T. H. Nylen, K. L. MacClune, and G. L. Dana (2006), Glacier mass balances (1993-2001), Taylor Valley, McMurdo Dry Valleys, Antarctica, J. Glaciol., 52(178), 451-462, doi:10.3189/ 172756506781828511.

Genthon, C., P. Lardeux, and G. Krinner (2007), The surface accumulation and ablation of a coastal blue-ice area near Cap Prudhomme, Terre Adélie, Antarctica, J. Glaciol., 53(183), 635-645, doi:10.3189/ 002214307784409333

Gooseff, M. N., W. B. Lyons, D. M. McKnight, B. H. Vaughn, A. G. Fountain, and C. Dowling (2006), A stable isotopic investigation of a polar desert hydrologic system, McMurdo Dry Valleys, Antarctica, Arct. Antarct. Alp. Res., 38(1), 60-71, doi:10.1657/1523-0430(2006) 038[0060:ASIIOA]2.0.CO;2.

Jaros, C. (2003), Temperature-elevation effect on glacial meltwater generation in dry valley streams, M.S. thesis, 91 pp., Univ. of Colo., Boulder.

Johnston, R. R., A. G. Fountain, and T. H. Nylen (2005), The origin of channels on lower Taylor Glacier, McMurdo Dry Valleys, Antarctica, and their implication for water runoff, Ann. Glaciol., 40, 1-7, doi:10.3189/ 172756405781813708.

Keys, J. R. (1980), Air Temperature, Wind, Precipitation and Atmospheric Humidity in the McMurdo Region, Victoria, Antarct. Data Ser., vol. 10 Victoria Univ., Wellington.

Lewis, K. J. (2001), Solar-forced roughening of Antarctic glaciers and the Martian icecaps: How surficial debris and roughness affect glacial melting in Taylor Valley, Antarctica and how this can be applied to the Martian icecaps, Ph.D. thesis, 182 pp., Univ. of Colo., Boulder.

Lewis, K. J., A. G. Fountain, and G. L. Dana (1998), Surface energy balance and meltwater production for a Dry Valley Glacier, Taylor Valley, Antarctica, Ann. Glaciol., 27, 603-609.

Lewis, K. J., A. G. Fountain, and G. L. Dana (1999), How important is terminus cliff melt? A study of the Canada Glacier terminus, Taylor Valley, Antarctica, Global Planet. Change, 22, 105-115, doi:10.1016/ S0921-8181(99)00029-6.

Liston, G. E., and K. Elder (2006), A meteorological distribution system for high-resolution terrestrial modeling (MicroMet), J. Hydrometeorol., 7 , 217-234, doi:10.1175/JHM486.1.

Liston, G. E., J. G. Winther, O. Bruland, H. Elvehoy, and K. Sand (1999), Below-surface ice melt on the coastal Antarctic ice sheet, J. Glaciol., 45(150), 273-285.

McKnight, D. M., D. K. Niyogi, A. S. Alger, A. Bomblies, P. A. Conovitz, and C. M. Tate (1999), Dry Valley streams in Antarctica: Ecosystems waiting for water, BioScience, 49(12), 985-995, doi:10.2307/1313732.

Mölg, T., and D. R. Hardy (2004), Ablation and associated energy balance of a horizontal glacier surface on Kilimanjaro, J. Geophys. Res., 109(D16), D16104, doi:10.1029/2003JD004338.

Nylen, T. H., A. G. Fountain, and P. T. Doran (2004), Climatology of katabatic winds in the McMurdo Dry Valleys, southern Victoria Land, Antarctica, J. Geophys. Res., 109, D03114, doi:10.1029/2003JD003937.

Paterson, W. S. B. (1994), The Physics of Glaciers, 480 pp., Pergamon, Oxford, U. K.

Priscu, J. C., C. F. Wolf, C. D. Takacs, C. H. Fritsen, J. Laybourn-Parry, E. C. Roberts, B. Sattler, and W. B. Lyons (1999), Carbon transformations in a perennially ice-covered Antarctic lake, BioScience, 49, 9971008, doi:10.2307/1313733.

Reijmer, C., W. Greuell, and J. Oerlemans (1999), The annual cycle of meteorological variables and the surface energy balance on Berkner Island, Antarctica, Ann. Glaciol., 29, 49-54, doi:10.3189/ 172756499781821166

Schmidt, R. A. (1982), Vertical profiles of wind speed, snow concentration and humidity in blowing snow, Boundary Layer Meteorol., 23, 223-246, doi:10.1007/BF00123299.

Stearns, C. R., and G. A. Weidner (1993), Sensible and latent heat flux estimates in Antarctica, in Antarctic Meteorology and Climatology: Studies Based on Automatic Weather Stations, Antarct. Res. Ser., vol. 61, edited by D. A. Bromwich and C. R. Stearns, pp. 109-138, AGU, Washington, D.C. Takahashi, S., T. Endoh, N. Azuma, and S. Meshida (1992), Bare ice fields developed in the inland part of Antarctica, Proc. NIPR Symp. Polar Meteorol. Glaciol., 5, 128-139.

Taylor, G. (1916), With Scott: The Silver Lining, Erskine, London.

Van Den Broeke, M., and R. Bintanja (1995), The interaction of katabatic winds and the formation of blue-ice areas in east Antarctica, J. Glaciol., 41(138), 395-407.

Wendler, G. (1986), The "radiation paradox" on the slopes of the Antarctic continent, Polarforschung, 56(1-2), 33-41.

Wendler, G., N. Ishikawa, and Y. Kodama (1988), The heat balance of the icy slope of Adelie Land, eastern Antarctica, J. Appl. Meteorol., 27(1), 52-65, doi:10.1175/1520-0450(1988)027<0052:THBOTI $>2.0 . C O ; 2$.

Winther, J.-G., H. Elvehøy, C. Egede Bøggild, K. Sand, and G. Liston (1996), Melting, runoff and the formation of frozen lakes in a mixed snow and blue-ice field in Dronning Maud Land, Antarctica, J. Glaciol., $42(141), 271-278$.

A. G. Fountain and M. J. Hoffman, Department of Geology, Portland State University, P.O. Box 751, Portland, OR 97207, USA. (hoffman@pdx. edu)

G. E. Liston, Cooperative Institute for Research in the Atmosphere, Colorado State University, Fort Collins, CO 80523-1375, USA. 